\title{
UKRAINE IN THE GERMAN MEDIA IN THE CONTEXT OF POLITICAL TRANSFORMATIONS IN THE INTERWAR PERIOD (BASED ON THE MATERIALS OF DAILY “DILO")
} Marian Zhytaryuk ${ }^{7}$, Victoria Zhytaryuk ${ }^{2}$

\begin{abstract}
This article presents the analysis of thematic, historical and political spectrums of the "Ukrainian" content in the German newspapers and magazines of the interwar period.

As a source base for this scientific work the authors analyze the newspaper and magazine journalism of that time, which allows not only to keep certain historical episodes (konstatives), but also (in some way) to reflect the views, needs, intentions, challenges, promises as well as German political and social factors in terms of disillusionment of Ukrainian patriotic forces (performatives).

Nazism and Bolshevism skillfully used propaganda to achieve predatory targets, therefore it should be a lesson for the future generations, also the importance of conceptional media in Ukraine and Poland should increase.
\end{abstract}

Key words: newspaper "Dilo", German press, propaganda, Hitler, interwar period, Ukraine

\section{Introduction}

In the interwar period (20-30s XX century) Ukraine was divided into the spheres of political influences among four powers - the USSR, Poland, Czechoslovakia and Romania. By logic, this situation did not only involve the Ukrainians, who tried to get the independence but it also had to affect European political establishment, which did not seem to approve either Nazism or Bolshevism [Zhytariuk, 1997]. The stubborn discrediting and unnoticing of Ukraine not only on the political but also on the geographical map, opened the already half-opened door to Bolshevism advance to the West. Although not recognized as a political state by anyone, Ukraine managed to save Europe. It was done by Ukrainian peasants and intellectuals who organized the resistance to Bolsheviks. They rejected the new, strange and violent methods of control and management. New ideals, collectivization, komsomol, communism, atheism and many more outraged the Ukrainians, who resisted to Moscow's innovations. Innovations that led to the destruction of

\footnotetext{
Doctor of sciences in social communications, professor of foreign press and information department of journalism, Lviv University, e-mail: mgzhyt@gmail.com

2 Journalist, researcher, translator
} 
human identity in general, and Ukrainian individuality in particular. Moscow ideologists and security officers brutally punished Ukrainians who were left by Europe at the mercy of the Bolshevik Party: Genocide of 1932-1933, numerous trials of intellectuals and Ukrainian Party activists, "cannibalization" as well as deportations to Siberia and other remote areas of Soviet Union. To summarize it in numbers: more than 10 million people were killed, almost every family was orphaned. That was the real price of protecting Europe from the Bolshevik plague. The European press, though in significant delay, wrote about famine, terror and prosecution for political believes in Soviet Union, but the European political establishment did not fail to notice all this.

\section{Presentation of problems in the German media}

European problems first led to the escalating of political power, and then to the prevail of the Third Reich military. Italian fascism gave the place to German Nazism. Here's how those concepts were characterized by the editor of the German monthly "Die Völkerbrücke", one of the leading political publicist in "Dilo" Mykola Trotsky, who spoke under the pen-name M. Danko: "The basis of Italian fascism is society, the basis of German fascism, when applying this term to Hitlerism, is politics. Italian fascism was born by the state inner need to defend against Bolshevism, the German fascism was born by the need to change those external terms in which Germany found itself" [Danko, 1933, p. 1].

Later historians will find out that Ukrainian patriots were right and in that they were fault. On the eve of the Second World War there was no time to consider. Everywhere - in Poland, Romania, Czechoslovakia and especially in the USSR - Ukrainians, at the best, felt uncomfortable. The First World War gave independence to many European countries. Conscious Ukrainians knew that nobody gives freedom - it has to be won.

But how would it be possible? Would there be any allies? It was difficult for the Ukrainians to count on the support of the governments and parliaments of European countries in the creation of Ukrainian state. Therefore Ukrainian leaders had to seek allies even among those, as time would tell, who were not sincere in their public statements. It is, for example, an indoctrination and overuse of brochure by Alfred Rosenberg "Ukraine as a host of world policy", which was published in 1928 or the interview of Karl Motts (the leader of the eastern department of National and Socialist Party), who on the pages of Lviv magazine "Chas" assured Ukrainians that "National-socialists want to see in the East Europe the firm Ukrainian National state" [Chas, 1932].

A sensational statement by Adolf Hitler (published in Lviv daily "Dilo" on 2nd April 1933) was the most divulged. It was perceived, clearly with different reception in Soviet Union as well as by the Ukrainian patriots in Galychyna. The statement, extracts of which are presented below, was announced at a press conference for foreign journalists: "The government, which is fighting against violence of victors over the defeated, cannot look quietly at the enslavement of the Ukrainians and people of Caucasus by Russian and Jewish communists. So we settled to liquidate our ally's terms from Rapallo and Berlin and do our best in order to suppress Communism in its Moscow cell and to help Ukraine in its liberation movements. Only decay of Bolshevism and the rise of new strong Ukrainian state can introduce the equilibrium of international forces in Europe and peace all over the world!" [Dilo, 1933, p.3].

German sympathies for the Ukrainians somewhat paradoxically were published by the Warsaw correspondent of the magazine "Kurier Poranny" Stanvey Filipson: "Rosenberg (...) asserts that Soviet Russia quickly smashed into several independent states; especially Large Ukraine will become almost absolutely independent from Poland in not very long time..." [Kurier Poranny,1933].

Among numerous background press records in the German press about the socalled pacification policy against peasants in Eastern Galychyna in autumn 1930 appeared: "Awakened Ukraine" [Probudzhena Ukraina, 1930], "On dark days of one mi- 
nority" [Z dniv lykholittia odniiei menshosti,1930], "The rampart against Bolshevism" [Protybilshovytskyi val, 1930], "Ukrainian liberation struggle" [Ukrainska vyzvolna borotba, 1930]. The subject was discussed on pages of "Deutschland", "Berliner Tageblatt" and other issues.

Former French Prime Minister E. Erio, well-known in Europe as an ardent adherent of Soviet Union, argued either on high political stands or on the pages of press that the famine of 1932-1933 is an invention of communism opponents, mainly Nazis. Having returned from Soviet Union, he began to publish in Paris diary "Information" series of articles under the title "Russian researches". Among his many assaults on Ukraine, E. Erio also quoted German magazine: "The whole campaign about famine in Ukraine is from Berlin (...) What's the aim of this campaign? It is easy to be open when we take up a magazine "Folk und Reich", issued by the German government and specially dedicated to Eastern Europe affairs. In one of its latest issues there is an article about how to create an Ukrainian state, which will be maintained by Germany and England" [Erio, 1933].

Throwing light upon protests against anti-bolshevism and "Ukrainian community in Germany", German newspapers published a "Call for Cultural World": "During the time when communist rule is for Moscow an internal matter, for Ukraine it is an occupation violence. The Ukraine's struggle is a struggle for the existence of a large nation, but a nation without rights, which got used to fighting and using the sword from centuries. Its healthy organism will conquer the Bolshevik contagion and will remain its national separateness" [Zaklyk do kulturnoho svita, 1936].

On January, 231937 two German dailies - "Der Angriff" (one of the leading German nationalist and socialist newspaper) and Berlin's "Der Völkischer Beobachter" published an article entitled "The Day of Ukrainian independence" [Den ukrainskoi nezalezhnosti, 1937]. Publicists in "Dilo" as well as the whole Galician emigration and intelligentsia (Great Ukraine lived different life and, except for the collectivization and Bolshevism, saw nothing), considered the appearance of this article as a "political event" ["Ukraina musyt buty vilna", 1937].

In February, the organ of nationalist and socialist youth's guide Baldur von Schirach's "Wille und Macht" published an article by Tyl Alce (on 9 pages) "The tragedy of Ukraine", in which among others, there was such a summary: "... because lack of attention Ukraine became a soviet republic" [Tyl, 1937].

Worried about major political matters, one of the most notable Ukrainian publicists, the last editor of Lviv daily "Dilo" Ivan Kedryn-Rudnytsky (died in 1995 in USA, at the age of 99) in his conceptual writing "Democracy, communism, nationalism and the Ukrainian National sense" explained mass admiration among Ukrainians of the ideas of Germany the Third Reich. He wrote: "...the most negative side of democracy is its weak point. The weak point shown in the fight with the communism (as a system) and with Bolshevism (as a form of expression) is the greatest enemy of democracy", "...In fight with communism as an idea, only nationalism can play the decisive role today, and in the fight against Soviets as Moscow state - the state with fascist system", "... When the Ukrainian democrat must choose between two antidemocratic streams of martial nationalism or communism of fascist and Moscow - we have to choose martial nationalism" [Kedryn, 1937].

Due to an entirely isolation of Ukraine by other states quite frequently political figures of different ranks stated that their countries would not have any business with Ukrainian national minorities (that was a typical view of Hitler's Germany), which after 1933 became a typical view for the whole Europe: "For our embassy in Warsaw only Poland with the citizens of the Polish state exists, no matter what their nationalities are, and for our Embassy in Moscow only Soviet-Ukrainian union state in the USSR exists" [Nimtsi y ukrainska probliema, 1930]. Considering the unprecedented fact that the USSR was accepted into the League of Nations, and also had chairmanship role in that international 
organization, last hopes for a fair trial of Ukrainian's aspirations towards the creation of their own state were lost.

Ukrainian patriotic forces found themselves quite alone with their troubles. Sometimes they (as anti-communists) were morally supported by German Nazis. Ukrainians in Galychyna had no choice but Ukrainians in the USSR were not even allowed to think in a "not soviet way". Political Ukrainian figures and publicists repeatedly claimed that they did not accept many methods of nationalist and socialist party ("Dilo as a democratic organ cannot accept the exclusive nature of the German nationalistic movement" [Hitlier, zhydy y ukraintsi, 1933], "Hitlerism is the psychological extreme necessity of German people” [Danko, 1933], "...Ukrainians are ready to co-operate with each state, which will maintain their National program. We can hardly speak about some special sympathy of Ukrainians to Germany (...) Some evidence of that is the fact that the number of political emigration in Germany is not as great as in other countries..." [M-n, 1935], "...when we have the people who admire Italian and German ideas and want to transfer them into our ground, we must not forget that (...) everywhere, where nationalism of fascist type is given the space - the national dominant majority displays its exclusivity and intolerability to the national minority, trying to enlarge its national status at the expense of national minorities" [Kedryn, 1937], "...Not all that is going on in Germany the Third Reich caused Ukrainian admiration..." [I. K., 1938]). Making a compromise with Bolsheviks (who seemed to have one aim - to eliminate Ukrainian nation from the face of the earth) - meant the worst choice.

Soviet historiography, like Putin's propaganda, turned the historical reality into overall lies. It turned out as if Ukrainian nationalists were enemies for their Motherland. But the one who is not mistaken is the one who does nothing.

Despite all psychological, ethical and financial difficulties caused by the awareness of being minority, Ukrainians did not toady to the Nazis and did not make up to Nazi Germany. Thus, in the publication "Ukraine and Europe. Ukrainian problem as an important political factor in the international politics" it is unequivocally said that "the rapid development of important political events in Europe "had formed" in some Ukrainians erroneous view that Ukraine is not a meaningful factor in the political life of Europe, but only an object of current political events of great powers. The creation of such false view was caused in a certain extent by Bolshevik press reports, which suggested that Germany and Poland planned to colonize Ukraine, and even separate it..." [Ukraina y Evropa, 1935].

How was this problem interpreted in the European press? Irish "Cork Examiner", for example, published a huge article "Hitler wants Ukraine. What do the Ukrainians say about it?", "Hitler wants to occupy Ukraine. But nobody mentions the word about the Ukrainians, about the role they are ready to play in the conflict that will catch on them in the first place...". "Cork Examiner" corresponds: "Does Germany want to extend its economic influence on Ukraine? Yes, it wants. But "to conquer" Ukraine? Never! The most plausible is that Hitler wants to conclude a modus vivendi with Ukrainians to set out together against their greatest enemy. Ukrainians are ready to agree with such a solution because it can bring them freedom which they wish so much" [Hitlier khoche Ukrainy, shcho na tse skazhut ukraintsi, 1938]. Unfortunately, the Irish were wrong.

In 1935 an authoritative Prague weekly "Economic review" in the article "Painful Ukraine" presumed that Germany had an ambiguous plans about Ukraine: "On one hand, Germany wants to take away so-called Polish Corridor, for which Poland would get a free hand on Ukraine, on the other hand - it wants to seize economically Ukraine's rich natural resources" [Boliucha Ukraina, 1935], [M-N, 1935].

Discussions about Ukrainian and German relations were carried out in 30s of XX century quite often. One of the most exhaustive discussion is presented in this article. In 1938 daily "Dilo" published the answer [I. K., 1938] to Polish edition of "Polityka UNDO w świetle autonomicznej deklaracji Centralnego Komitetu UNDO z dnia 7. maja 1938 r. 
Lwów" [Pełeński, 1938]. Ukrainian publicist (hidden under an alias) was indignant that the Polish author could not see the difference between the Russians and Germans and wished Poland to be "strong and fit for fighting both with Moscow and Germans as Ukraine cannot count on anything good neither from Moscow nor from Germany", "We have no grounds to be guided by love to Germany and Germans, but also we have no grounds to be anti-German", "Then the matter is (...) about formation of Ukrainian attitude to Germans and Germany the Third Reich in its current legal and state form, we have to contend with such immutable facts:

1. there were not and there will not be any territorial disputes,

2. there was not, there is not and cannot be any fight for the ethnic character of the land, where there is not any assimilation efforts,

3. there is not any cultural rivalry,

4. there are not any relationships such as between conqueror and vanquished.

In other words, there are not Ukrainian and German relationships, all these impartial, geographical, historical and political moments created a permanent conflict between Poland and Germany". Moreover, the Ukrainian political commentator cites very interesting and valuable in the context of the raised topic (but it is difficult to say how accurate it is) information that "German press, abiding under the close state control, devotes to Ukrainian theme more place than the press of all Western states together" [I. K., 1938].

September 1938 was the beginning of great disappointment. German promises were empty. The Nazis stopped emphasizing the importance of Ukrainian state. They had other - more advantageous and more far-seeing-plans. The world would find out about this in less than a year - when tanks tracks were stained with Ukrainian patriots' blood, with blood of defenders of Trans-Carpathian Ukraine.

In one of his speeches Adolf Hitler said: "I am sympathizing with the fate of Slovaks, Poles, Ukrainians and Magyars. But I am the speaker only of the fate of my Germans" [Promova Hitliera ta Zakarpattia, 1938]. Ukrainians did not like those words. The future of Trans-Carpathian Ukraine still remained uncertain. Nationalism and socialism as an ideology was only the display of German imperialism and did not carry new, far-reaching aspiration for the new national morals and justice between people and nations - such an assumption seems quite logical. Afterwards German political players forgot their speeches about Ukrainian independence. They used Czech short-sighted attempts to convert into centralize system in Slovakia and Carpathian Ukraine and the reaction in the Slovak Carpathian-Ukrainian community on complete liquidation of Federation. Although the Slovaks knew German intentions, they did not warn Ukrainians of Transcarpathia.

There were confirmed messages in foreign media, including the "Paris-Soir" [Paris-Soir, 1939] and "Gazeta Polska" [Gazeta Polska, 1939] that German government had agreed to liquidate Carpathian Ukraine to "enable the existence of common Polish-Hungarian border" [Rozviiani omany, 1939]. Chancellor Hitler considered stopping of German forces on the borders of the Carpathian Ukraine "not only for Magyars, but first of all for Poland". In the Ukrainian part of the speech Hitler dethroned two misconceptions: "The Vienna arbitration as an act of international justice and people's self-determination - in German interpretation..." [Rozviiani omany, 1939]. That only confirmed the old truth that politics is often a dirty business, and morality in politics is often only a mean of political struggle. But all this leads to a detailed separation of political romance and sentiment from political realism. "Political romance is to have claims to Hitler for that he reached unattainable heights and saw the problem of Carpathian Ukraine from another point of view (...)" [Rozviiani omany, 1939].

It was difficult to understand those diverse thoughts and the rapid development of political events on the eve of the Second World War. But at least Ukrainian political forces had the courage to admit their own mistakes. 


\section{Finally}

Emotional statements of Hitler were too good to become true. Nazism, like Bolshevism, skillfully used its propaganda and even today it is difficult to say clearly how sincere were wishes of independence to Ukrainian people issued in German press.

History of 30 s in Europe is very similar to Ukrainian contemporary events - the annexation of Crimea by Kremlin invaders, the war in Donbas organized by putinists and Russian military men, anti-Ukrainian hysteria organized by Moscow propagandists in Europe and all over the world. The aim of all this is to destroy Ukrainian position in the eyes of the West and to destroy friendly relations between Poland and Ukraine (Poland as a lawyer of Ukraine).

\section{References}

BOLIUCHA UKRAINA (1935), [in:] Hospodarskyi rozghliad: Prazkyi tyzhnevyk, issue Lyst. Chas: Lvivskyi chasopys (1932), issue 12th January.

DANKO M. (1933), Hitlieryzm i bolshevyzm, [in:] Dilo, issue 17th March, p. 1.

Den ukrainskoi nezalezhnosti (1937), [in:] Anhrif: Natsional-sotsiialistychnyi shchodennyk, issue 23rd January. DILO (1933), issue 2nd April, p. 3.

ERIO E. (1933), Rosiiski studii [Tsykl statei], [in:] Information: Paryzkyi shchodennyk, issue Lystopad. Gazeta Polska (1939), issue 26th April.

Hitlier khoche Ukrainy, shcho na tse skazhut ukraintsi (1938), [in:] Cork Examiner: Irlandskyi chasopys, issue 7th May.

Hitlier, zhydy y ukraintsi. Pretensii "Khvili" do ukrainskoi presy (1933), [in:] Dilo, issue 20th April. p. 1.

I. K. (1938), Za samostiinyi ukrainskyi pidkhid do inshykh narodiv, [in:] Dilo, issue 14th August, p.1-2.

IK. (1939), Za shcho maiemo zhal do nimtsiv? [in:] Dilo, issue 26th March, p. 2.

KEDRYN, I. (1937), Demokratiia, komunizm, natsionalizm ta ukrainska natsionalna ratsiia, [in:] Dilo, issue 4th, 6th, 7th, 9th July.

Kurier Poranny (1933), Warszawa, issue 5th May.

M-N (1935), "Koly svit perekonaietsia, shcho my - ye". Zamitnyi chekhoslovatskyi holos pro ukrainsku spravu? [in:] Dilo, issue 29th November, p. 2.

Nimtsi y ukrainska probliema (1930), [in:] Dilo, issue 23rd September., p. 1.

PARIS-SOIR (1939), issue 24th April.

PEŁEŃSKI, Z. P. (1938), Polityka UNDO w świetle autonomicznej deklaracji Centralnego Komitetu UNDO z dnia 7. maja 1938 r., Lwów: Nasze Słowo.

Probudzhena Ukraina (1930), [in:] Reweitsche Zeitung, issue 24th October.

Promova Hitliera ta Zakarpattia (1938), [in:] Dilo, issue 29th September, p.1-2.

Protybilshovytskyi val (1930), [in:] Deutsche Tageszeitung, issue 25th October.

Rozviiani omany (Z pryvodu "ukrainskoho" ustupu promovy kantsliera Hitliera) (1939), [in:] Dilo, issue 4th May, p. 2.

TYL A. (1937), Trahediia Ukrainy, [in:] Volia y Mohutnist: Dvotyzhnevyk natsional-sotsiialistychnoi molodi Nimechchyny, issue 15th February.

Ukraina y Evropa. Ukrainska probliema vazhnym politychnym chynnykom u mizhnarodnii politytsi (1935), [in:] Dilo, issue 26th May, p. 2-3.

"Ukraina musyt buty vilna" (Preharna stattia u dvokh peredovykh berlinskykh shchodennykakh) (1937), [in:] Dilo, issue 27th January, p. 2-3.

Ukrainska vyzvolna borotba (1930), [in:] Allen Steiner Zeitung, issue 30th October.

Z dniv lykholittia odniiei menshosti (1930), [in:] Munchener Neues Nachrichten, issue 25th October.

Zaklyk do kulturnoho svita (1936), [in:] Berliner Bersen Zeitung, issue 5th September.

ZHYTARIUK M. (1997), Chetvertovana, ale zhyva. Zakordonna presa pro politychni protsesy v Ukraini naperedodni Druhoi svitovoi viiny: Monohrafiia, Lviv: Za vilnu Ukrainu, p. 128. 